\title{
Research Productivity of Faculty Members of Taharabad College: A Scientometric Study
}

\author{
Dr. Fulari Arjun Ramdas
}

Librarian, MVP'S Arts Commerce and Science College Taharabad, Tal. Baglan, Dist. Nashik-423302

\begin{abstract}
The Twenty-first century shaped a new atmosphere for education. Due to computer technology, internet, smart phones and other such devices, education reached to each and every corner of the world. Even people living in remote areas are able to reap the benefits of open education system and distance education system

This paper presents a scientomentric study of Arts and Commerce College i.e. research productivity of faculty members during 2019-2021. This research paper covers gender wise, age group wise, writing/publication statues of teachers, language wise research productivity, use of communication channel for research, purpose of research productivity, and authorship pattern.
\end{abstract}

Keywords: Scientometric, Research Productivity, Authorship pattern, Geographical Distribution, Motivational Factor

\section{Article Publication}

Published Online: 12-Nov-2021

*Author's Correspondence

$\S$ Dr. Fulari Arjun Ramdas

8 Librarian, MVP'S Arts Commerce and Science College Taharabad, Tal. Baglan, Dist. Nashik-423302

$\triangle$ arjunrfulari@gmail.com

$\underline{10.31305 / \text { rrijm.2021.v06.i11.006 }}$

(C) 2021The Authors. Published by RESEARCH REVIEW International Journal of Multidisciplinary. This is an open access article under the CC BY-

NC-ND license

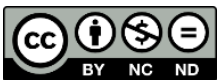

(https://creativecommons.org/licenses/ by-nc-nd/4.0/)

\section{Introduction}

Research productivity in higher education is gaining importance from the past one decade in India. Faculty members of the universities have two functions to perform, e.g. teaching and research. Research has now become the very significant aspect of scholarly communication involving theses, dissertations, conference proceedings, books, patents, journals, articles, etc. It is important to undertake the analysis of the research outputs in the different disciplines.

Scientometric is the science of measuring and analyzing science. In practice, scientometric is often done using bibliometrics that is measurement of scientific publications. In1960, Vassily V. Nalimove had coined the term scientometric. Modern scientometric is primarily based on the work of Derek J. de solla price and Eugene Garfield. The later founded the Institute of Scientific Information (ISI), which carries out scientometric analysis. Scientometric studies broadly constitute quantitative analysis of scientific literature to reveal the latest developments in various fields and the patterns of geographical distribution of science and scientific productivity of individual nation.

\section{About Arts and Commerce College and its library}

Maratha Vidya Prasarak Samaj's 'Arts and Commerce College, Taharabad Tal. Baglan, Dist. Nashik (M. S.)' is growing slowly and steadily to cater to the educational needs of the aspirant youths of Taharabad and the nearby villages by offering UG courses in Arts and Commerce faculties. To see the improvement in the lives of the masses, this college has been established in 1997 with herculean efforts of the parent institute MarathaVidya 
Prasarak Samaj, Nashik, founded in 1914 with the motto 'Bahujan Hitay, Bahujan Sukhay' (Mass Education for the Welfare of the Massess). The aim of the founder members was to lead the downtrodden, backward and tribal masses from the darkness to light, from illiteracy to higher education from ignorance to knowledge. The college is striving hard to bear the responsibility shouldered by the pioneers to meet the educational needs of the residents of the region.

There is a common library for both the courses which is completely equipped with the latest technology to turn into efficient library and information services to its users. The college library is soul of the college. The library has compilation of five thousand books, CDs/DVDs, 12 produce journals, 200 bound volumes of journals. NlistInflibnet subscribed online database.

\section{Definitions of the key terms:}

\section{Research:}

The eminent scholars from the library field have defined 'Research'. The word research is made up of two morphemes viz.'re' and 'search'. Here,'re' means again and 'search' means to investigate. This states that research is an inquiry after the search. It is the investigation of the problem done with specific point of view. It is prominently observed that research is an inquiry. Inquiry does mean the exploration into the particular problem to the root cause of problems and to get proper solutions.

\section{Productivity:}

Cambridge learner's dictionary defines the productivity means the rate at which goods is produced.

\section{Definition of Research Productivity}

It is but general that the number of publishing any product helps in calculating the productivity of an academic. If an individual productivity of a librarian is considered, it is measured by analyzing at higher education. The status of an academic depends on the counting of the published products.

Research productivity on behalf of Librarians is also considered the issue of prestige because the knowledge of the librarian helps the entire community of the academic institute. The research work done by the librarian also brings prestige to the institute.

\section{Review of Literature}

Golwal (2020) conducted a bibliometric study on publication productivity of Information literacy in Scopus database. The research published on information literacy in Scopus database from the year 1999-2018. It shows that majority of $9.67 \%$ research work published throughout 2018, followed by $09.20 \%$ from the year 2016 and 08.99\% during the year 2017. It indicated that top 10 research scholar from total literature output in the information literacy. Amid the total number of 20610 publications, the utmost research articles were contributed by M.S. Wolf. The huge research articles were in the category of social science with $18.49 \%$.

Parmar et.al.(2020) The study seek out out the 50 years research output on OSMF at universal stage. It was founded that an entire number of 1451 papers were published for the period of 1967-2016. There were received 24963 citations. In the block year 2007-2011, the growth rate was utmost (94.15\%). India was the highest country by publication

Lokhande and Lihitkar (2019)As far as the present topic of research is concerned, Solapur University has analyzed the $\mathrm{Ph}$. D. theses from Science faculty awarded in between 2008 and 2018. The researcher has used qualitative method to do the research. The researcher has considered the study in as per the years in which theses submitted and awarded. He analyses them guide wise and subject wise. From the data it is concluded that 
Geography, physics and chemistry research is in stable increase pattern whereas statistics and Botany is minimum it may be due to availability of guides. Geography and chemistry guides have highest contribution in research with maximum number of students with Ph.D.

Garg and Tripathi(2018) Conducted the study on highlights the contents of published articles in various disciplines. There were 902 articles published by Indian scholars for the period of 1995-2014. The highest number $23 \%$ of article published in India. The field of medicine has published highest number as compared to other discipline.

Sivakumar(2017) conducted the study to explore the research productivity of the academic members of PSG college of arts and science in between 2001 and 2015 from the Scopus database. In this research study, 430 research papers were selected which were published during the study period. It is found that most of the research articles were published in 2015 and the number is 69. The entire number of citation received by the articles was 3938 and the total citing articles were 284.The h-index of PSG colleges 31.

\section{Objectives of the study:}

The most important objective of the study is to examine the research productivity of faculty members working in Arts and commerce college Taharabad affiliated to SPPU Pune for the period of 2019 to 2021.

1. To analyze research productivity of faculty members of Arts and commerce college during 2019 to 2021.

2. To find out the research productivity pattern (authorship pattern)

3. To know gender wise research productivity.

4. To examine the communication channel preferred for publication of college research output.

\section{Hypothesis of present study}

1. The research papers of faculty members are published in UGC- listed journal more than conference and seminar

2. Mainstream of faculty members publish their research work in English language.

3. Working environment motivate the faculty members to publication.

4. Faculty members facing the language problem to publish the research paper.

\section{Research Methodology}

The present study will adopt survey method using questionnaire as a tool of data collection. A structured questionnaire was designed with the help of Google form and link is distributed to the teachers i.e. faculty members of Arts and commerce college Taharabad. Also in addition to online Google form and offline printed questionnaire was prepared to collect the data required for the present study and 17 were received back. The response rate is $100 \%$.

To collect the primary data from them, the researcher has prepared a common questionnaire taking into considerations all the common facilities of the campuses. The questionnaires then sent to them for filling in the information and collected within a stipulated time. After analyzing the questionnaires, the researcher has interviewed some of the samples to clear doubts rose while going through the questionnaires. The interviews helped to strengthen the data and clear the doubts to avoid the restriction of the research.

\section{Data analysis and Interpretation}

The statistics of faculty members in Arts and Commerce College are 19 out of them 17 have respondent, 02 have not respondent. The composed information has been analyzed with using subsequent parameters. Gender wise, types of research contribution, year wise, age wise, Language wise, authorship patterns, motivational factors, used of the communication channel for research, Barriers in research productivity. 


\section{Gender wise research productivity}

Gender wise publication statues of Arts and commerce college faculty members affiliated to SPPU, Pune. The collected data is analyzed in table no.7.1

Table 7:1 Gender wise research productivity

\begin{tabular}{|l|l|l|l|l|}
\hline Sr. No. & Gender faculty & No. of Respondent & Publication & Percentage $(\%)$ \\
\hline 1. & Male & 13 & 47 & $66.20 \%$ \\
\hline 2. & Female & 04 & 24 & $33.80 \%$ \\
\hline 3. & Total & 17 & 71 & $100 \%$ \\
\hline
\end{tabular}

It can be experimental from table no.7.1 that present are total 71 publications. Male faculty members have produced $66.20 \%$ research articles whereas female faculty members have produced $33.80 \%$ publications. It shows that male faculty members have more research output than female faculty members.

\section{Types of research contribution:}

Research output in symposia, seminar, conferences, journals, book chapters, books, research projects, and patents of college teachers affiliated to SPPU. The collected data is analyzed in table no.7.2

Table 7.2 Types of research productivity

\begin{tabular}{|c|l|l|l|l|l|l|}
\hline Sr. No. & Types of Research productivity & 2018 & 2019 & 2020 & Total & Percentage \\
\hline 1. & Symposia & 3 & 5 & 5 & 13 & $12.62 \%$ \\
\hline 2. & Seminar & 2 & 3 & 5 & 10 & $9.70 \%$ \\
\hline 3. & Conference & 2 & 2 & 7 & 11 & $10.68 \%$ \\
\hline 4. & Journal & 9 & 14 & 21 & 44 & $42.73 \%$ \\
\hline 5. & Book chapters & 3 & 3 & 8 & 14 & 13.59 \\
\hline 6. & Books & 2 & 4 & 3 & 9 & $8.74 \%$ \\
\hline 7. & Research project (MRP) & 1 & 1 & 0 & 2 & $1.94 \%$ \\
\hline 8. & Patents & 0 & 0 & 0 & 0 & \\
\hline & Total & 22 & 32 & 49 & 103 & $100 \%$ \\
\hline
\end{tabular}

Table no. 7.2 indicates types of research productivity such as symposia, seminars, conferences, journals, book chapters, research products, and patents. There are 103 research articles produced during the year 2019 to 2021. The greater part of research scholars has produced research articles in journals $42.73 \%$; followed by seminar $9.70 \%$. Nobody registered for any patents.

\section{Year wise research productivity:}

Table no 7.2 demonstrates that there is total 103 research articles. 2021 was the more research productive year in comparative to the number of publications. In 2021 research produced 49 research articles in symposia, seminars, conferences, journals, book, book chapters, research projects etc. The less research productive year was 2019 has only 22 research articles. It shows that productivity of faculty members increases year by year. It is increasing than earlier year.

\section{Age wise research productivity}

The mainstream of the faculty members is belonging to $31-40$ age groups. $23.54 \%$ and $5.88 \%$ are belonging to 41 50 age groups and 51-60 respectively. 21-30 age group researchers have not produced any research articles. Majority of research paper are belonged to 31-40 age group have published 70.54\% research articles.

Table 7.5 Age wise research productivity

\begin{tabular}{|l|l|l|l|l|l|}
\hline Sr. No. & Age group & Respondent & Percentage of respondent & publication & percentage \\
\hline 1. & $21-30$ & 0 & & 0 & \\
\hline 2. & $31-40$ & 12 & $70.58 \%$ & 91 & $88.35 \%$ \\
\hline 3. & $41-50$ & 04 & $23.54 \%$ & 12 & $11.65 \%$ \\
\hline 4. & $51-60$ & 1 & $5.88 \%$ & 0 & \\
\hline & & & $100 \%$ & 103 & $100 \%$ \\
\hline
\end{tabular}




\section{Language wise research productivity:}

The bulk number 70\% faculty members are using English, 23\% faculty members used Marathi and 5\% teachers using Hindi language for research publication.

Table 7.6 Language wise research productivity

\begin{tabular}{|l|l|l|l|}
\hline Sr. No. & Preferred language & No. of respondent & Percentage of respondent \\
\hline 1. & English & 12 & $70.58 \%$ \\
\hline 2. & Marathi & 04 & $23.54 \%$ \\
\hline 3. & Hindi & 01 & $5.88 \%$ \\
\hline
\end{tabular}

\section{Authorship pattern}

It can be distinguished from table no. 7.7 that $70.58 \%$ faculty members using single authorship pattern followed by $17.64 \%$ doubled authorship pattern; and $11.76 \%$ faculty members preferred three authorship patterns in their research work publication. no one use more than three authorship pattern for their publication.

Table 7.7 Authorship pattern

\begin{tabular}{|l|l|l|l|}
\hline Sr. No. & Authorship pattern & No of respondent & percentage of respondent \\
\hline 1. & Single Author & 12 & $70.58 \%$ \\
\hline 2. & Double Author & 3 & $17.64 \%$ \\
\hline 3. & More than three author & 2 & $11.76 \%$ \\
\hline & Total & 17 & \\
\hline
\end{tabular}

\section{Communication channels use for research}

The table no. 7.8 indicates that preponderance of research scholar used journals for their research producations, i.e. $76.47 \%$ Journals for research.

Table 7.8 Communication channels use for research

\begin{tabular}{|l|l|l|l|}
\hline Sr. No. & Communication channel use for research & No. of respondent & percentage of respondent \\
\hline 1. & Journals & 13 & $76.47 \%$ \\
\hline 2. & Books & 3 & $17.64 \%$ \\
\hline 3. & Conference proceeding & 6 & $35.29 \%$ \\
\hline 4. & MRP & 2 & $14.28 \%$ \\
\hline & Total & 17 & \\
\hline
\end{tabular}

\section{Purpose of research}

Mainstream of the $47.05 \%$ faculty member's research purpose is to improve knowledge followed by $41.17 \%$ is to get promotion and to upgrade qualification $11.76 \%$.

Table 7.9 Purpose of your research

\begin{tabular}{|l|l|l|l|}
\hline Sr. No. & Purpose of research & No of respondent & Percentage of respondent \\
\hline 1. & To upgrade knowledge & 8 & $47.05 \%$ \\
\hline 2. & To get promotion & 7 & $41.17 \%$ \\
\hline 3. & To upgrade qualification & 2 & $11.76 \%$ \\
\hline 4. & To get a job & 0 & \\
\hline & Total & 17 & \\
\hline
\end{tabular}

\section{Financial support for research}

It is experiential that the table no. 7.10 greater part of $76.47 \%$ researchers pending individuality on research activity; whereas $11.76 \%$ research scholar started that college provides finance for research movement. Nobody gets UGC and fellowship for research. 
Table 7.10 Financial support for your research

\begin{tabular}{|l|l|l|l|}
\hline Sr. No. & Financial support for research & No. of respondent & percentage of respondent \\
\hline 1. & UGC & 0 & \\
\hline 2. & BCUD-University & 2 & $11.76 \%$ \\
\hline 3. & College & 2 & $11.76 \%$ \\
\hline 4. & Self & 13 & $76.47 \%$ \\
\hline & Total & 17 & \\
\hline
\end{tabular}

\section{Major Findings}

1) Male faculty members have produced $66.20 \%$ research articles, while female faculty members have produced $33.80 \%$ research work. It shows that male faculty members have more research produced than female faculty members.

2) The common of research scholars have produced research work in journals $42.73 \%$ followed by chapters in book is $13.59 \%$

3) Majority of faculty members preferred English language to publish research work.

4) Majority of faculty members expenditure self on research activity.

\section{Conclusion}

The Present study is based on survey, interview, observation to find out research productivity of the faculty members in Arts and commerce college Taharabad affiliated to SPP University, Pune. It has sheltered the gender wise, types of research contribution, year wise, , age wise, writing publication statues, language wise, who provides financial support for your research, research project statues, Authorship pattern, and motivated factor in productivity, authorship position, Barriers in research productivity etc.

\section{References}

Bagadi, K., Angadi, M. \&Koganuramath, M. (2012). Scientometric dimensions of social psychology research in the Asian region. Journal of Indian Library Association, 48, (3), 44-47.

Bottle, R, Hassain, S, Bottle, A \&Adsanya, O. (1994). The productivity of British,American and Nigerian chemist compared. Journal of Information Science, 2, 211 - 215.

Dricet, S \&Katare, V. (2010). Publication productivity of the scientists of the centralInstitute for Catton Research; A Bibliometric study, LASLIC Bulletin, 55(2), 158.

Garfield, E. (1972). Citation analysis as a tool in journal evolution. Science, 178 (60), 471- 479.

Hattie, John... et al. (1994). The productivity of Australian Academies in Education.AustralianJournal of Education, 38 (3), $201-218$.

Kothari, C. (2010). Research Methodology: Methods and Techniques. New Delhi: New age International Publishers.

Kumar P.. (2002). A student's Manual of Library and Information Sciences. B.R.publishing, New Delhi.

Veeramani, K. \&Sivaraman, P. (2011). Research Trends in Chemistry of India, 20012010: An Empirical Analysis. Library Progress (International), 31 (1), 111-117

Vijaykumar, M, (2012). Webometric Analysis of University Websites in Sri Lanka. International Journal of Information Dissemination and Technology, 2 (3), 155- 159. 